\title{
Influence of Environmental Pollution on Leaf Properties of Urban Plane Trees, Platanus orientalis L.
}

\author{
Alireza Pourkhabbaz $\cdot$ Nayerah Rastin • \\ Andrea Olbrich · Rosemarie Langenfeld-Heyser • \\ Andrea Polle
}

Received: 12 December 2009/Accepted: 11 June 2010/Published online: 25 June 2010

(C) The Author(s) 2010. This article is published with open access at Springerlink.com

\begin{abstract}
To investigate whether leaves of plane trees (Platanus orientalis) are damaged by traffic pollution, trees from a megacity (Mashhad, Iran) and a rural area were investigated. Soil and air from the urban centre showed enrichment of several toxic elements, but only lead was enriched in leaves. Leaf size and stomata density were lower at the urban site. At the urban site leaf surfaces were heavily loaded by dust particles but the stomata were not occluded; the cuticle was thinner; other anatomical properties were unaffected suggesting that plane trees can cope with traffic exhaust in megacities.
\end{abstract}

Keywords Air pollution - Filtering - Heavy metal . Leaf anatomy

Air pollution is a serious problem in many heavily populated and industrialized areas in the world (Kambezidis et al. 1996). A growing share of the world's population is living in urban centers and is demanding a cleaner environment. In many urban areas of the world, motor vehicle traffic is a major source of air pollution contributing $57 \%-75 \%$ of total emissions (WHO 2006). In general, metropolitan areas have higher pollution than rural areas (Lagerwerff and Specht 1970; Sawidis et al. 1995, 2001). Air pollutants from motor vehicle exhausts have both direct

\footnotetext{
A. Olbrich · R. Langenfeld-Heyser · A. Polle $(\bowtie)$

Forest Botany and Tree Physiology, Büsgen-Institute,

Georg-August-University Göttingen, Büsgenweg 2,

37077 Göttingen, Germany

e-mail: apolle@gwdg.de

A. Pourkhabbaz $\cdot$ N. Rastin

University of Applied Sciences and Arts (HAWK),

Büsgenweg 1a, 37077 Göttingen, Germany
}

and indirect effects on the metabolism of roadside plants even before visible symptoms appear (Viskari et al. 2000). Urban forests and trees in the urban environment can improve air quality through filtering and uptake of gases and particles (Beckett et al. 2000). Therefore, urban trees are of high importance for the inhabitants, but may also be endangered by exposure to pollution. For example, in leaves of a typical urban roadside tree species, Platanus orientalis air pollution caused changes in chlorophyll content and peroxidase activities (Alaimo et al. 2000; Baycu et al. 2006). In various roadside plants exposure to road traffic emissions resulted in changes in foliar anatomy and morphology and caused visible injury (Ghouse et al. 1980; Jahan and Iqbal 1992; Pandey and Agrawal 1994; Verma et al. 2006; Joshi and Abhishek 2007). Foliage from trees near air pollution sources can even be 'coated' with particulates (Ricks and Williams 1974; Lerman and Darley 1975), which may cause stomatal occlusion, thus, leading to reduced photosynthesis (Williams et al. 1971).

Plane (Platanus orientalis) trees are widely planted in parks and along streets in southern Europe and middle Asia to improve the microclimate. The purpose of this study was to determine air and soil pollution in the center of the megacity Mashad (Iran) and its periphery (Torghabeh) and to investigate functional properties of plane leaves under these conditions.

\section{Materials and Methods}

The urban study site was in the city of Mashhad $\left(36^{\circ} 41^{\prime} \mathrm{N}\right.$, $52^{\circ} 39^{\prime} \mathrm{E}$, elevation $985 \mathrm{~m}$ above sea level, Iran) with a population of ca 2.1 million. The city is visited each summer by several hundred thousand pilgrims. The rural site was Torghabeh, an area at a distance of about $20 \mathrm{~km}$ 
Table 1 Heavy metal concentrations in soil, air and leaf blades of Platanus orientalis trees from an urban and a rural site

\begin{tabular}{|c|c|c|c|c|c|c|}
\hline \multirow[t]{2}{*}{ Element } & \multicolumn{2}{|l|}{ Soil } & \multicolumn{2}{|l|}{ Air } & \multicolumn{2}{|l|}{ Leaves } \\
\hline & Urban $\left(\mu \mathrm{g} \mathrm{g}^{-1}\right)$ & $\operatorname{Rural}\left(\mu \mathrm{g} \mathrm{g}^{-1}\right)$ & Urban $\left(\mathrm{ng} \mathrm{m}^{-3}\right)$ & Rural (ng m ${ }^{-3}$ ) & Urban $\left(\mu \mathrm{g} \mathrm{g}^{-1}\right)$ & Rural $\left(\mu \mathrm{g} \mathrm{g}^{-1}\right)$ \\
\hline $\mathrm{Pb}$ & $31.2 \pm 5.2$ & $14.6 \pm 1.0^{* * *}$ & $98.2 \pm 32.0$ & $7.5 \pm 3.1 * * *$ & $4.5 \pm 1.9$ & $1.9 \pm 0.9 * * *$ \\
\hline $\mathrm{Zn}$ & $109.1 \pm 7.8$ & $89.0 \pm 13.7 * *$ & $4.8 \pm 1.4$ & $2.0 \pm 0.7$ & $76.8 \pm 17.7$ & $78.7 \pm 12.5$ \\
\hline $\mathrm{Ni}$ & $93.7 \pm 10.4$ & $107.2 \pm 10.0$ & $31.2 \pm 16.0$ & $24.0 \pm 19.0$ & $4.2 \pm 1.0$ & $4.4 \pm 1.3$ \\
\hline Co & $6.1 \pm 0.5$ & $6.2 \pm 0.5$ & $2.3 \pm 2.0$ & $0.7 \pm 0.6^{*}$ & $0.3 \pm 0.1$ & $0.4 \pm 0.1$ \\
\hline $\mathrm{Cr}$ & $202.6 \pm 22.8$ & $164.2 \pm 27.4^{* * *}$ & $49.6 \pm 4.3$ & $9.3 \pm 2.2 * *$ & $2.4 \pm 0.7$ & $1.7 \pm 0.6$ \\
\hline $\mathrm{Cu}$ & $33.0 \pm 3.9$ & $40.9 \pm 7.7 * *$ & $42.0 \pm 8.6$ & $44.2 \pm 7.8$ & $13.0 \pm 3.5$ & $14.5 \pm 3.4$ \\
\hline
\end{tabular}

Data are means per site of $\mathrm{n}=5$ for soil, $\mathrm{n}=4$ for air and $\mathrm{n}=10$ for leaf samples $( \pm \mathrm{SD})$. Significant differences determined by Student's $t$ test are indicated as follows: $p \leq 0.001$ by ***, $p \leq 0.01$ by **, and $p \leq 0.05$ by *, respectively

from the city centre. The climate in this area is semi-arid with an annual average temperature of $13.5^{\circ} \mathrm{C}$ and an annual sum of precipitation of $248 \mathrm{~mm}$. At each site 10 Platanus orientalis (L.) trees of a height of about 8-10 m were selected. Leaf samples were collected about 4-5 m above ground in May and September 2004 and 2005, air samples about $12 \mathrm{~m}$ above ground three times a season in 2005 and soil samples from 0 to $0.1 \mathrm{~m}$ depth in September 2005 , respectively.

Leaves were either immediately fixed in FAE $(37 \%$ formaldehyde, $96 \%$ acetic acid, $70 \%$ ethanol) at a ratio of 5:5:90 (v/v) and later preserved in 70\% ethanol or dried. Leaf area was measured by an Image Analysis System (WINDIAS, Delta-T Devices Ltd, Burwell, Cambridge, UK). Cross sections (30 $\mu \mathrm{m}$ thick) were prepared from fixed leaf material with a freezing microtome (Reichert, Wien, Austria). The specimen were photographed under a light microscope (Axioplan, Zeiss, Oberkochen, Germany) with a digital camera (Nikon Coolpix 4500, Nikon, Tokyo, Japan) and used to measure the length and width of palisade cells and area of palisade and spongy parenchyma cells with the software Image J (NIH, Wayne Rasband; http://rsbweb.nih.gov/ij/). In addition leaf cross sections were stained with the lipid fluorochrome fluorol yellow 088 ( $0.01 \%$ fluorol yellow 088 (Sigma F-5520) in polyethylene glycol 400 (Merck 8.07485) (Brundrett et al. 1991) and photographed under a fluorescence microscope (Axioplan;

Table 2 Leaf properties of Platanus orientalis trees from an urban and a rural site

\begin{tabular}{lcc}
\hline Leaf parameter & Urban site & Rural site \\
\hline Leaf area $\left(\mathrm{cm}^{2}\right)$ & $179 \pm 47$ & $213 \pm 60^{* * *}$ \\
Stomatal density $\left(\right.$ no $\left.\mathrm{mm}^{-2}\right)$ & $227 \pm 50$ & $314 \pm 31^{* *}$ \\
Stomatal pore width $(\mu \mathrm{m})$ & $5.2 \pm 1.1$ & $7.6 \pm 1.1^{* *}$ \\
Cuticle thickness $(\mu \mathrm{m})$ & $4.9 \pm 0.7$ & $7.2 \pm 0.8^{*}$ \\
\hline
\end{tabular}

Data are means per site of $\mathrm{n}=10( \pm \mathrm{SD})$. Significant differences determined by Student's $t$ test are indicated as follows: $p \leq 0.001$ by $* * *, p \leq 0.01$ by $* *$, and $p \leq 0.05$ by $*$, respectively
UV-filter combination G 365 FT 395 LP 420; Zeiss, Oberkochen, Germany) with a digital camera (Zeiss Axiocam MRC, Software AxioVision Rel. 4.6). Leaf pieces were excised from fixed material, cleared in $10 \% \mathrm{NaOH}$ $\left(65^{\circ} \mathrm{C}, 24 \mathrm{~h}\right.$, washed twice with water), stored in $70 \%$ ethanol, documented under a light microscope (Axioplan) using a digital camera (Nikon Coolpix 4500) and used to measure length, width and area of stomatal pores with Image J.

Dry leaf samples from three selected trees per site were studied under a scanning electron microscope (SEM 515, Philips, The Netherlands); specimen were sputtered with gold in a vacuum coating unit (SC 500, Emscope, Ashford, United Kingdom) as described by Robinson et al. (1987).

Aliquots of dry leaves and soil were powdered and wetashed at $170^{\circ} \mathrm{C}$ in $\mathrm{HNO}_{3}$ for $12 \mathrm{~h}$ (Feldmann 1974). The heavy metal concentrations were measured by inductively coupled plasma atomic emission spectroscopy (Heinrichs et al. 1986). To determine air pollution four $24 \mathrm{~h}$-collections of air were conducted per site with a high volume air sampler (Dehm \& Zinkeisen, Frankfurt, Germany) which sucks air, aerosols and particles through Teflon filters (Fluopore membrane filters, Millipore). The filters were extracted in $\mathrm{HNO}_{3}$ and analyzed as above.

Data are means of $n=10 \pm$ SD trees per site, if not indicated other wise. Means were compared by Student's $t$-test using STATGRAPHICS Plus (St. Louis, ML, USA). $p$-Values $\leq 0.05$ were considered to indicate significant differences and are shown by $*$ for $p \leq 0.05$, ** for $p \leq 0.01$ and by $* * *$ for $p \leq 0.001$.

\section{Results and Discussion}

Soils from the urban site contained higher concentrations of lead, zinc, chromium, and copper than that of the rural site (Table 1). The concentrations were still within regulatory limits defined for soils in the European community (Polle and Schützendübel 2003). Elevated concentrations 
of lead, cobalt and chromium were present in urban air (Table 1). The highest enrichment in air was found for lead. Only lead was accumulated to a higher extent in leaves from the urban than in those from the rural site (Table 1). As lead is a heavy metal with low plant mobility (Günthardt-Goerg and Vollenweider 2007), uptake of lead into plane leaves from the soil is unlikely. It can be assumed that the enhanced lead concentration in leaves from urban planes was filtered from the air. In other cities, e.g. Istanbul, even higher lead concentrations were found in Platanus orientalis leaves than in our study (Baycu et al. 2006).

To find out if exposure to the urban environment affected functional leaf properties, we determined leaf area, stomatal density and opening (Table 2). Young expanding
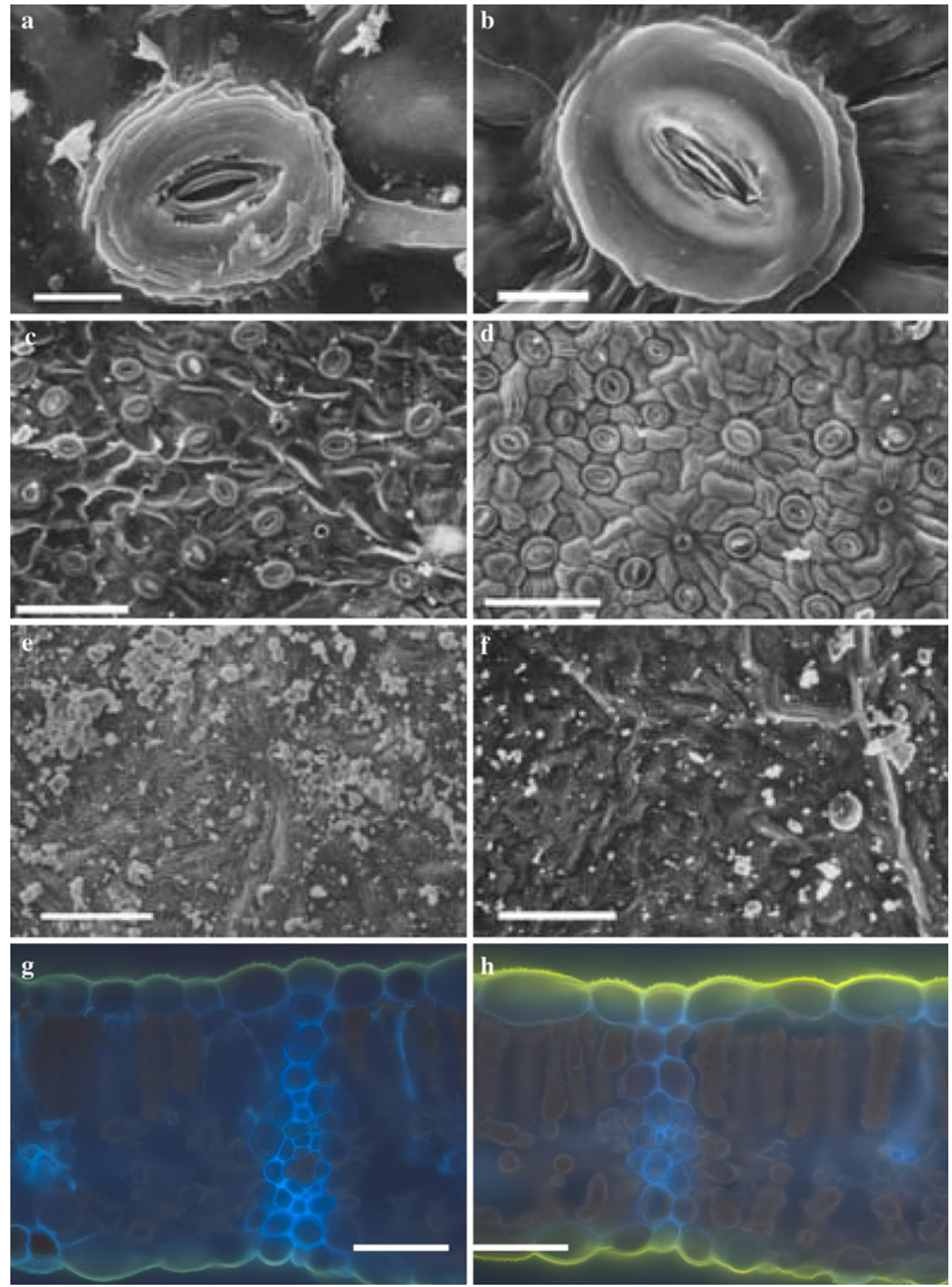

Fig. 1 Anatomical leaf properties of Platanus orientalis trees from an urban and a rural site. Stomata with guard cells from an urban (a) and a rural site $(\mathbf{b})$, scale bars $=10 \mu \mathrm{m}$. Lower surface of plane leaves from an urban (c) and a rural site (d), scale bars $=100 \mu \mathrm{m}$.

Upper surface with particles of planes from an urban (e) and a rural site (f), scale bars $=100 \mu \mathrm{m}$. Cross sections through leaves from an urban $(\mathbf{g})$ and a rural site $(\mathbf{h})$, scale bars $=50 \mu \mathrm{m}$ 
leaves showed no differences in mean leaf areas $\left(84 \pm 23 \mathrm{~cm}^{2}\right)$. Mature leaves from the urban area were smaller than those from the rural site (Table 2). This suggests an influence of air pollution on leaf expansion. Similarly, significant growth reductions have also been reported for leaves from other tree species in heavily polluted city areas (Platanus acerifolia, Ficus bengalensis, Guaiacum officinale and Eucalyptus sp., Ninova et al. 1983; Jahan and Iqbal 1992).

Furthermore stomatal density and stomatal widths were lower on leaves from the urban than on those from the rural site (Table 2) but not stomatal lengths $(12.5 \pm 2.0 \mu \mathrm{m})$. Negative effects of air pollutants on stomatal densities and opening have also been found in other species such Trifolium repens, Trifolium pratense, Cicer arietenum, Acer saccharum and Ipomea pes-tigridis growing in polluted areas (Sharma and Butler 1973, 1975; Garg and Varshney 1980; Ghouse et al. 1980; Verma et al. 2006). A reduction of stomata is also found in response to elevated $\mathrm{CO}_{2}$ concentrations, frequently present in city centres (Williams et al. 1986). The reduction in stomatal densities and their pore size may be important for controlling absorption of pollutants (Verma et al. 2006), but will limit photosynthesis at the same time.

In spite of exposure to higher pollution at the urban site, the anatomy of stomata from both study sites appeared normal (Fig. 1a, b). Each stoma had a raised rim over the guard cell region, which is typical for plane (Carpenter et al. 2005). Notably, the guard cells appeared more shrunken on the polluted leaves (Fig. 1c, d). A collapsed lower epidermis, as described by Günthardt-Goerg and Vollenweider (2007) for translocated $\mathrm{Zn}$ in Populus tremula leaves, was not be detected.

Foliage close to pollutant sources can be 'coated' with particles (Ricks and Williams 1974; Lerman and Darley 1975; Godzik et al. 1979). Studies of the diffusion resistance of leaves of Quercus petraea covered with such particulates suggested that they interfere with the control of stomatal closing (Ricks and Williams 1974). In contrast, Godzik et al. (1979) reported that the leaves of plants covered with particulates showed no pollution-dependent effects on stomatal closure. Our SEM examinations showed that the stomata of $P$. orientalis leaves were not plugged by particulates (Fig. 1a-d), although dust particles were present on the leaf surface. At the urban site the particles were abundant and clumped together, whereas they were less frequent and more scattered on leaves from the rural site (Fig. 1e, f).

In spite of differences in surface properties, cross sections of leaves did not reveal anatomical abnormalities (Fig. 1g, h). Cytological parameters such as lengths, widths and projected cell area of palisade parenchyma cells (means: $57 \pm 20,12.7 \pm 2.9 \mu \mathrm{m}, 548 \pm 176 \mu \mathrm{m}^{2}$ ) and area of the spongy parenchyma cells $\left(243 \pm 64 \mu \mathrm{m}^{2}\right)$ did not differ between the urban and the rural sites, respectively. However, the cuticle covering the outer epidermal layer was much thinner in leaves from trees at the urban than on those of leaves from trees grown at the polluted site (Fig. 1g; Table 2). The yellow lipid staining also indicated incorporation of less cutin and the blue autofluorescence pointed to higher accumulation of phenolics at the urban compared with the rural site (Fig. 1g, h). A thinner cuticle may enhance transpiration.

In conclusion, our study shows that urban conditions affected structural leaf properties, which may lead to lower photosynthesis through lower leaf area, lower stomatal densities and pore widths and probably higher sensitivity to drought because of a thin cuticle. However, mainly leaf surface features, but not internal functional anatomy, were affected. These results support that plane trees can cope with pollution (Dickinson et al. 1991) and therefore, are suitable roadside trees for megacities. The observation that leaves in urban environments were strongly covered by dust particles suggests that plane may contribute significantly to improving air quality (Smith and Staskawicz 1977). To determine the extent of air filtration and tolerance to traffic exhaust, controlled studies have to be performed in future.

Acknowledgments ARP is grateful to the Islamic Republic of Iran for providing a $\mathrm{PhD}$ scholarship.

Open Access This article is distributed under the terms of the Creative Commons Attribution Noncommercial License which permits any noncommercial use, distribution, and reproduction in any medium, provided the original author(s) and source are credited.

\section{References}

Alaimo MG, Lipani B, Lombardo MG, Orecchio S, Turano M, Melati MR (2000) The mapping of stress in the predominant plants in the city of Palermo by lead dosage. Aerobiol 16:47-54

Baycu G, Tolunay D, Özden H, Günebakan S (2006) Ecophysiological and seasonal variations in $\mathrm{Cd}, \mathrm{Pb}, \mathrm{Zn}$, and $\mathrm{Ni}$ concentrations in the leaves of urban deciduous trees in Istanbul. Environ Pollut 143:545-554

Beckett KP, Freer-Smith PH, Taylor G (2000) Particulate pollution capture by urban trees: effect of species and windspeed. Glob Change Biol 6:995-1003

Brundrett MC, Kendrick B, Peterson CA (1991) Efficient lipid staining in plant material with Sudan red 7B or Fluorol Yellow 088 in polyethylene glycol-glycerol. Biotech Histochem 66:111-116

Carpenter RJ, Hill RS, Jordan GJ (2005) Leaf cuticular morphology links Platanaceae and Proteaceae. Intern J Plant Sci 166:843-855

Dickinson NM, Turner AP, Lepp NW (1991) Part III: Survival of trees in a metal-contaminated environment. Water Air Soil Pollut 57-58:627-633

Feldmann C (1974) Perchloric acid procedure for wet-ashing organics for the determination of mercury (and other metals). Anal Chem 46:1606-1609 
Garg KK, Varshney CK (1980) Effect of air pollution on the leaf epidermis at the sub microscopic level. Experientia 36:13641366

Ghouse AKM, Zaidi H, Attique A (1980) Effect of air pollution on the foliar organs of Callistemon citrinus Stapf. J Sci Res 2: 207-209

Godzik S, Florkowski T, Sassen MMA (1979) An attempt to determine the issue contamination of Quercus robur L. and Pinus silvestris L. foliage by particulates from zinc and lead smelters. Environ Pollut 18:97-106

Günthardt-Goerg M, Vollenweider P (2007) Linking stress with macroscopic and microscopic leaf response in trees: new diagnostic perspectives. Environ Pollut 147:467-488

Heinrichs H, Brumsack HJ, Loftfield N, König N (1986) Verbessertes Druckaufschlussystem für biologische und anorganische Materialien. Z Pflanzenernähr Bodenkd 149:350-353

Jahan S, Iqbal MZ (1992) Morphological and anatomical studies of leaves of different plants affected by motor vehicles exhaust. J Islamic Acad Sci 5:21-23

Joshi PC, Abhishek S (2007) Physiological responses of some tree species under roadside automobile pollution stress around city of Haridwar, India. Environmentalist 27:365-374

Kambezidis HD, Adamopoulos AD, Gueymard C (1996) Total $\mathrm{NO}_{2}$ column amount over Athens, Greece in 1996-97. Atmos Res $57: 1-8$

Lagerwerff JV, Specht AW (1970) Contamination of road soil and vegetation with cadmium, nickel, lead, and zinc. Environ Sci Tech 4:583-586

Lerman FF, Darley EF (1975) Particulates. In: Mudd JB, Kozlowski TT (eds) Responses of plants to air pollution. Academic Press, New York, pp 141-158

Ninova DJ, Dushkova PI, Kovacheva CV (1983) Anatomical, morphological studies of Platanus acerifolia at various degrees of air pollution. Ekologiya (Sofia) 6:35-47

Pandey J, Agrawal M (1994) Evaluation of air pollution phytotoxicity in a seasonally dry tropical urban environment using three woody perennials. New Phytol 126:53-61

Polle A, Schützendübel A (2003) Heavy metal signalling in plants: linking cellular and organismic responses. In: Hirt H, Shinozaki $\mathrm{K}$ (eds) Plant responses to abiotic stresses, vol 4, Topics in current genetics. Springer, Berlin, pp 167-215
Ricks GR, Williams RJH (1974) Effects of atmospheric pollution on deciduous woodland part 2: effects of particulate matter upon stomatal diffusion resistance in leaves of Quercus petraea (Mattuschka) Leibl. Environ Pollut 6:87-109

Robinson DG, Ehlers U, Herken R, Herrmann B, Mayer F, Schürmann F-W (1987) Methods of preparation for electron microscopy. Springer, Berlin

Sawidis T, Marnasidis A, Zachariadis G, Stratis J (1995) A study of air pollution with heavy metals in Thessaloniki city (Greece) using trees as biological indicators. Arch Environ Contam Toxicol 28:118-124

Sawidis T, Chettri MK, Papaioannou A, Zachariadis A, Stratis J (2001) A study of metal distribution from lignite fuels using trees as biological monitors. Ecotoxicol Environ Saf 48:27-35

Sharma GK, Butler J (1973) Leaf cuticular variations in Trifolium repens L. as indicators of environmental pollution. Environ Pollut 5:287-293

Sharma GK, Butler J (1975) Environmental pollution: leaf cuticular patterns in Trifolium pratense L. Ann Bot 39:1087-1090

Smith WH, Staskawicz BJ (1977) Removal of atmospheric particles by leaves and twigs of urban trees: some preliminary observations and assessment of research needs. Environ Manag 1:317-330

Verma RB, Mahmooduzzafar, Siddiqui TO, Iqbal M (2006) Foliar response of Ipomea pes-tigridis L. to coal-smoke pollution. Turkish J Bot 30:413-417

Viskari EL, Surakka J, Pasanen P, Mirme A, Kössi S, Ruuskanen J, Holopainen JK (2000) Responses of spruce seedlings (Picea abies) to exhaust gas under laboratory conditions. I Plant-insect interactions. Environ Pollut 107:89-98

WHO (2006) Air quality guidelines for particulate matter, ozone, nitrogen dioxide and sulphur dioxide. Global update 2005. WHO Regional Office for Europe, Copenhagen, Denmark, ISBN 9289 021926

Williams RJH, Lloyd MM, Ricks GR (1971) Effects of atmospheric pollution on deciduous woodland I: Some effects on leaves of Quercus petraea (Mattuschka) Leibl. Environ Pollut 2:57-68

Williams WE, Garbutt K, Bazzaz FA, Vitousek PM (1986) The response of plants to elevated $\mathrm{CO}_{2}$. IV. Two deciduous-forest tree communities. Oecologia 69:454-459 